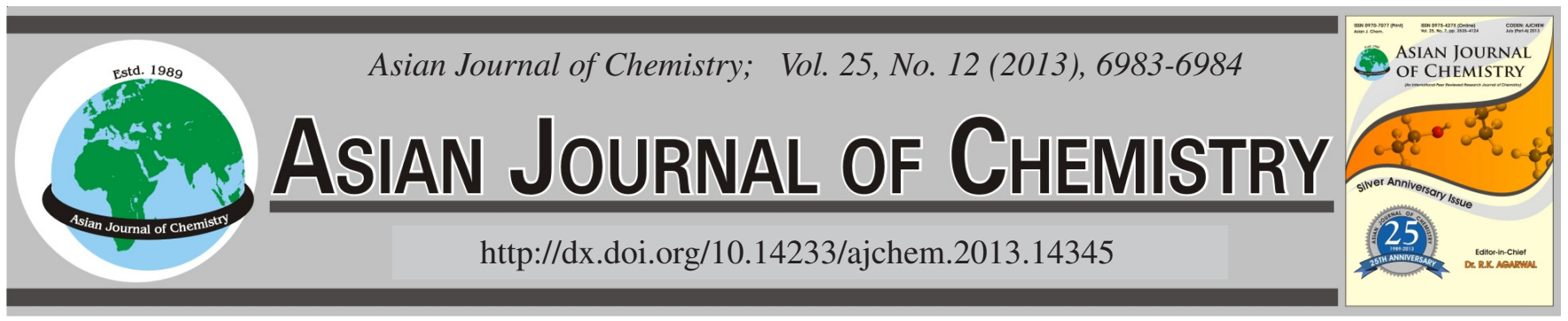

NOTE

\title{
A New Phenyl Propanoid from the Roots of Nicotiana tabacum and Its Biological Activities
}

Dingrong Mou ${ }^{1,2}$, Wei ZhaO ${ }^{2}$, Tao Zhang ${ }^{2}$, Wei Liu ${ }^{2}$, Guangyu Yang ${ }^{2}$, Yongkuan Chen ${ }^{2}$, Qiufen Hu ${ }^{3, *}$ and Mingming MiaO ${ }^{1,2, *}$

${ }^{1}$ Technology Center of Hongta Group, Yuxi 653100, P.R. China

${ }^{2}$ Key Laboratory of Tobacco Chemistry of Yunnan Province, Yunnan Academy of Tobacco Science, Kunming 650106, P.R. China

${ }^{3}$ Key Laboratory of Chemistry in Ethnic Medicinal Resources, State Ethnic Affairs Commission \& Ministry of Education, Yunnan University of Nationalities, Kunming 650031, P.R. China

*Corresponding authors: E-mail: huqiufena@yahoo.com.cn; mmmiao@cyats.com

A new phenylpropanoid, 3-hydroxy-1-(4,5-dimethoxyphenyl-2-O- $\beta$-D-glucopyranoside)-propan-1-one, was isolated from the roots of Nicotiana tabacum. Its structures were determined by means of HRESIMS, extensive 1D and 2D NMR spectroscopic studies and chemical evidence. Compound $\mathbf{1}$ was tested for its cytotoxicity against five human tumor cell lines and it show modest cytotoxic abilities against PC3 and MCF7 cell with $\mathrm{IC}_{50}$ values of 5.6 and $2.8 \mu \mathrm{M}$, respectively.

Key Words: 3-Hydroxy-1-(4,5-dimethoxyphenyl-2-O-ß-D-glucopyranoside)-propan-1-one, Nicotiana tabacum, Cytotoxicity.

ᄂ - - - - - - - - - - - - - - - - - - - - - - - - - - -

Nicotiana tabacum $\mathrm{L}$. is one of the most commercially valued agricultural crops in the world ${ }^{1,2}$. In addition to cigarette industry use, $N$. tabacum also contains many useful chemical compounds, such as sesquiterpenes ${ }^{3,4}$, diterpenoids ${ }^{5-7}$, alkaloids $^{8,9}$, phenols ${ }^{10}$, etc. Motivated by search for bioactive metabolites from this plant, an investigation on the chemical constituents of the roots of $N$. tabacum was carried out. As a result, a new phenylpropanoid (Fig. 1) was isolated from this plant. In addition, the cytotoxicity of phenyl propanoid (1) was evaluated. This article deals with the isolation, structural elucidation and cytotoxicity of this new phenyl propanoid.

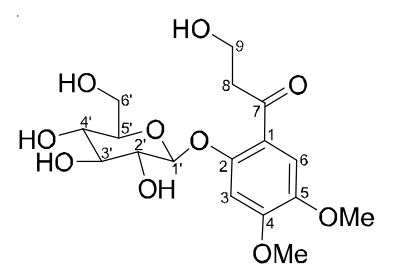

Fig. 1. Structure of compounds 1

UV spectra were obtained using a UV-2401A spectrophotometer. A Tenor 27 spectrophotometer was used for scanning IR spectroscopy with $\mathrm{KBr}$ pellets. 1D and 2D NMR spectra were recorded on DRX-500 spectrometers with TMS as internal standard. Chemical shifts $(\delta)$ were expressed in ppm with reference to the solvent signals. MS was performed on an API QSTAR time-of-flight spectrometer and a VG
Autospec-3000 spectrometer, respectively. Preparative HPLC was performed on a Shimadzu LC-8A preparative liquid chromatograph with a ZORBAX PrepHT GF $(21.2 \mathrm{~mm} \times$ $25 \mathrm{~cm}, 7.0 \mu \mathrm{m})$ column. Column chromatography was performed with Si gel (200.300 mesh, Qing-dao Marine Chemical, Inc., Qingdao, China), Lichroprep RP-18 gel (40.63 $\mu \mathrm{m}$, Merck, Darmstadt, Germany) and MCI gel (75.150 $\mu \mathrm{m}$, Mitsubishi Chemical Corporation, Tokyo, Japan). The fractions were monitored by TLC and spots were visualized by heating Si gel plates sprayed with $5 \% \mathrm{H}_{2} \mathrm{SO}_{4}$ in EtOH. Plant Material. The roots of the Chinese variety of $N$. tabacum (Honghua Dajinyuan) were collected in Dali Prefecture, Yunnan Province, P.R. China, in September 2012.

Extraction and isolation: The air-dried and powdered roots of $N$. tabacum $(2.2 \mathrm{~kg})$ were extracted four times with $70 \%$ methanol $(4 \times 2 \mathrm{~L})$ at room temperature and filtered. The crude extract (102 g) was applied to silica gel (200-300 mesh) column chromatography, eluting with a chloroformacetone gradient system $(20: 1,9: 1,8: 2,7: 3,6: 4,5: 5)$, to give five fractions A to $F$. The further separation of fraction $C$ (6:4, $35.2 \mathrm{~g})$ by silica gel column chromatography, eluted with chloroform-methanol $(9: 1,8: 2,7: 3,6: 4,1: 1)$, yielded mixtures C1-C5. Fraction C2 (8:2, $4.15 \mathrm{~g})$ was subjected to preparative HPLC (30\% methanol, flow rate $12 \mathrm{~mL} / \mathrm{min}$ ) to give compound 1 (35.6 mg).

Compound 1 was obtained as pale yellow gum. Its molecular formula was determined as $\mathrm{C}_{17} \mathrm{H}_{24} \mathrm{O}_{10}$ by HR-ESI-MS 
$\mathrm{m} / \mathrm{z} 387.1283[\mathrm{M}-\mathrm{H}]^{-}$(calcd. 387.1291). Its ${ }^{1} \mathrm{H}$ and ${ }^{13} \mathrm{C}$ NMR spectra (Table-1) showed signals to 24 hydrogens and 17 carbons, respectively, corresponding to one aromatic ring $\left(\delta_{\mathrm{C}}\right.$ $102.8,112.3,112.8,142.0,154.2,155.2)$ with two aromatic protons $\left(\delta_{\mathrm{H}} 6.82 \mathrm{~s}, 7.36 \mathrm{~s}\right)$, one methylene group $\left(\delta_{\mathrm{C}} 42.2\right)$, one oxidated methylene group $\left(\delta_{\mathrm{C}} 58.9\right)$, one carbonyl group $\left(\delta_{\mathrm{C}} 198.5\right)$, two methoxyl groups $\left(\delta_{\mathrm{C}} 55.6,56.2\right)$ and a a glucosyl moiety $\left(\delta_{\mathrm{C}} 104.3 \mathrm{~d}, 75.4 \mathrm{~d}, 78.3 \mathrm{~d}, 71.7 \mathrm{~d}, 78.0 \mathrm{~d}\right.$, and $62.8 \mathrm{t}$ ). Strong absorption bands accounting for hydroxyl $\left(3458,3376 \mathrm{~cm}^{-1}\right)$, carbonyl $\left(1728,1713 \mathrm{~cm}^{-1}\right)$ and aromatic group $\left(1630,1517,1455,1439 \mathrm{~cm}^{-1}\right)$ could also be observed in its IR spectrum. The UV spectrum of $\mathbf{1}$ showed absorption maxima at $285 \mathrm{~nm}$ confirmed the existence of the aromatic function. The ${ }^{1} \mathrm{H}-{ }^{1} \mathrm{H}$ COSY of $\mathrm{H}-8 / \mathrm{H}-9$; together with $\mathrm{HMBC}$ correlations (Fig. 2$)$ of H-6 $\left(\delta_{\mathrm{H}} 7.36\right)$ with C-7 $\left(\delta_{\mathrm{C}} 198.5\right)$, of H-8 $\left(\delta_{\mathrm{H}} 3.20\right)$ with $\mathrm{C}-1\left(\delta_{\mathrm{C}} 112.3\right)$, of H-9 $\left(\delta_{\mathrm{H}} 4.28\right)$ with $\mathrm{C}-7$ $\left(\delta_{\mathrm{C}} 198.5\right)$ and $\mathrm{C}-8\left(\delta_{\mathrm{C}} 42.2\right)$ suggested that 1 is a 3 -hydroxyl1-phenyl-1-propanone ( $\left.\mathrm{Ar}-\mathrm{CO}-\mathrm{CH}_{2}-\mathrm{CH}_{2} \mathrm{OH}\right)$ and it possess two methoxyl groups and a glucosyl moiety on the aromatic ring. The HMBC correlations of two methoxyl proton signals $\left(\delta_{\mathrm{H}} 3.82,3.85\right)$ with $\mathrm{C}-4\left(\delta_{\mathrm{C}} 154.2\right), \mathrm{C}-5\left(\delta_{\mathrm{C}} 142.0\right)$ indicated two methoxyl groups should be located at C-4 and C-5, respectively. The long-range correlations in the $\mathrm{HMBC}$ spectrum between $\mathrm{H}-1^{\prime}\left(\delta_{\mathrm{H}} 4.72 \mathrm{~d}\right)$ and $\mathrm{C}-2\left(\delta_{\mathrm{C}} 155.2 \mathrm{~s}\right)$ indicated the glucosyl was linked to $\mathrm{C}-2$ and the coupling constant value of $\mathrm{H}-1^{\prime}(J=7.35 \mathrm{~Hz})$ indicated that the glucosyl moiety was connected to the aglycone by a $\beta$-linkage ${ }^{11,12}$. On the basis of the above evidence, the structure of $\mathbf{1}$ was established as 3hydroxy-1-(4,5-dimethoxyphenyl-2-O- $\beta$-D-glucopyranoside)propan-1-one.

\begin{tabular}{|c|c|c|}
\hline \multicolumn{3}{|c|}{$\begin{array}{c}\text { TABLE-1 } \\
\left.{ }^{1} \mathrm{H} \text { AND }{ }^{13} \mathrm{C} \text { NMR DATA (IN CD }{ }_{3} \mathrm{OD}\right) \text { OF COMPOUND } 1 \\
\end{array}$} \\
\hline \multirow{2}{*}{ No. } & \multicolumn{2}{|c|}{ Compound 1} \\
\hline & $\delta_{\mathrm{C}}$ (mult.) & $\delta_{\mathrm{H}}($ mult $, J, \mathrm{~Hz})$ \\
\hline 1 & $112.3 \mathrm{~s}$ & - \\
\hline 2 & $155.2 \mathrm{~s}$ & - \\
\hline 3 & $102.8 \mathrm{~d}$ & $6.82 \mathrm{~s}$ \\
\hline 4 & $154.2 \mathrm{~s}$ & - \\
\hline 5 & $142.0 \mathrm{~s}$ & - \\
\hline 6 & $112.8 \mathrm{~d}$ & $7.36 \mathrm{~s}$ \\
\hline 7 & $198.5 \mathrm{~s}$ & - \\
\hline 8 & $42.2 \mathrm{t}$ & $3.20 \mathrm{t}, J=6.1$ \\
\hline 9 & $58.9 \mathrm{t}$ & $4.28 \mathrm{t}, J=6.2$ \\
\hline OMe-4 & $55.6 \mathrm{q}$ & $3.82 \mathrm{~s}$ \\
\hline OMe-5 & $56.2 \mathrm{q}$ & $3.85 \mathrm{~s}$ \\
\hline $1^{\prime}$ & $104.3 \mathrm{~d}$ & $4.72, \mathrm{~d}, J=7.2$ \\
\hline $2^{\prime}$ & $75.4 \mathrm{~d}$ & $3.47 \mathrm{~m}$ \\
\hline $3^{\prime}$ & $78.3 \mathrm{~d}$ & $3.46 \mathrm{~m}$ \\
\hline $4^{\prime}$ & $71.7 \mathrm{~d}$ & $3.30 \mathrm{~m}$ \\
\hline $5^{\prime}$ & $78.0 \mathrm{~d}$ & $3.30 \mathrm{~m}$ \\
\hline - & - & $3.68 \mathrm{~m}$ \\
\hline $6^{\prime}$ & $62.8 \mathrm{t}$ & $3.82 \mathrm{~m}$ \\
\hline
\end{tabular}

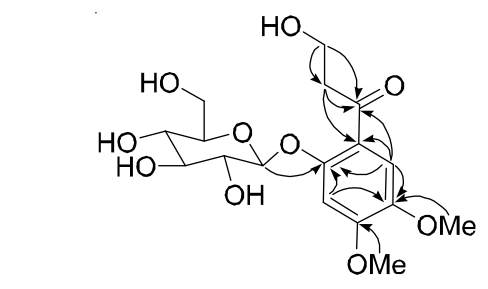

Fig. 2. Selected HMBC $(\frown)$ correlations of $\mathbf{1}$
Since certain of the phenyl propanoid derivatives exhibit potential cytotoxicity. Compound $\mathbf{1}$ was tested for their cytotoxicity against five human tumor cell lines (NB4, A549, SHSY5Y, PC3, and MCF7) using the MTT method as reported previously ${ }^{13}$. Taxol was used as the positive control. The results revealed the new compound showed low active $\left(\mathrm{IC}_{50}\right.$ values $>10 \mu \mathrm{M}$ ) for NB4, A549, and SHSY5Y tumor cell and showed modest cytotoxicity against $\mathrm{PC} 3$ and $\mathrm{MCF} 7$ cell with $\mathrm{IC}_{50}$ values of 5.6 and $2.8 \mu \mathrm{M}$, respectively.

3-Hydroxy - 1 - 4,5-dimethoxyphenyl-2-O- $\beta$-Dglucopyranoside)-propan-1-one: Obtained as pale yellow gum; UV (MeOH) $\lambda_{\max }(\log \varepsilon) 320$ (2.42), 285 (4.15), 250 (3.52), 210 (4.68) nm; IR (KBr, $\left.v_{\max }, \mathrm{cm}^{-1}\right)$ : 3458, 3376, 2922, 2854, 1728, 1713, 1630, 1517, 1455, 1439, 1363, 1282, 1165 , 1137, 1080, 1048, 975, 860; ${ }^{1} \mathrm{H}$ and ${ }^{13} \mathrm{C}$ NMR data $\left(\mathrm{C}_{5} \mathrm{D}_{5} \mathrm{~N}\right.$, $500 \mathrm{MHz}$ ), Table-1; positive ESIMS m/z 387 [M-H] $^{-}$; HRESIMS m/z 387.1291 [M-H] $^{-}$(calcd. (\%) 387.1291 for $\mathrm{C}_{17} \mathrm{H}_{23} \mathrm{O}_{10}$ ).

\section{ACKNOWLEDGEMENTS}

This project was supported financially by the Basic Research Foundation of Yunnan Tobacco Industry Co. Ltd. (2012JC01), the Excellent Scientific and Technological Team of Yunnan High School (2010CI08), and the Open Research Fund Program of Key Laboratory of Ethnic Medicine Resource Chemistry (Yunnan University of Nationalities) (2010XY08).

\section{REFERENCES}

1. The Editorial Committee of the Administration Bureau of Flora of China, Flora of China, Beijing Science and Technology Press, Beijing, Vol. 67 (2005).

2. T.W. Hu and Z. Mao, Tob. Control, 15, i37 (2006).

3. X. Feng, J.S. Wang, J. Luo and L.Y. Kong, J. Asian Nat. Prod. Res., 12, 252 (2010).

4. X. Feng, J.S. Wang, J. Luo and L.Y. Kong, J. Asian Nat. Prod. Res., 11, 675 (2009).

5. W. Inger, W. Ingrid, N. Kerstin, N. Toshiaki, R.E. Curt, W.R. William, Y. Noboru and Y. Chizuko, Acta Chem. Scand., 33b, 541 (1979).

6. Y. Shinozaki, T. Tobita, M. Mizutani and T. Matsuzaki, Biosci. Biotechnol. Biochem., 60, 903 (1996).

7. T. Petterson, A.M. Eklund and I. Wahlberg, J. Agric. Food. Chem., 41, 2097 (1993).

8. X.C. Wei, S.C. Sumithran, A.G. Deaciuc, H.R. Burton, L.P. Bush, L.P. Dwoskin and P.A. Crooks, Life Sci., 78, 495 (2005).

9. T. Braumann, G. Nicolaus, W. Hahn and H. Elmenhorst, Phytochemistry, 29, 3693 (1990).

10. D. Vereecke, E. Messens, K. Klarskov, A. Bruyn, M. Montagu and K. Goethals, Planta, 201, 342 (1997).

11. O. Fulvia, P. Francesca, B. Barbara and M. Giuliana, Carbohydr. Res., 301, 95 (1997).

12. S. Sianne, B.N. Zhou, E.G. Thomas, L.S. Jessica and G.I.K. David, J. Nat. Prod., 63, 457 (2000).

13. T. Mosmann, J. Immunol. Methods, 65, 55 (1983). 